\title{
Richard E. Wagner: James M. Buchanan and Liberal Political Economy: A Rational Reconstruction
}

\author{
Lexington Books, Lanham, Maryland, 2017, ix + 209 o.
}

A közösségi döntések elméletének vagy alkotmányos politikai gazdaságtannak négy iskoláját szokás elkülöníteni (Rowley [2008]): a virginiait, a rochesterit, a chicagóit és a politikai közgazdaságtant (political economics). Az elsőnek, a virginiai iskolának volt meghatározó és úttörő alakja a 2013-ban elhunyt James Buchanan, Wagner e nemrég megjelent kötetének hőse. A virginiai iskolát ismerőknek a Wagner névről valószínűleg a Democracy and Deficit ugrik be elsőre, James M. Buchanannel közösen írt könyve (Buchanan-Wagner [2000/1977]). Wagner tehát közeli kollégája és szerzőtársa is volt Buchanannek, s többek között ezért különleges ez a kötet: szerzője ötven éven keresztül állt szoros kapcsolatban Buchanannel mint tanítvány, mint kolléga és mint barát. Ebből az 50 évből 34 évet töltöttek ugyanazon az egyetemen (177. o.). Gordon Tullock 2014-es halála óta tehát valószínủleg nincs a világon olyan közgazdász, aki jobban ismerné James M. Buchanan munkásságát, mint Richard E. Wagner.

A James Buchanan-féle liberális politikai gazdaságtan nem népszerü Magyarországon - nekem legalábbis így tünik -, James Buchanan neve nem cseng annyira ismerősen, mint más, vele egyidős Nobel-díjasoké. Pedig az, hogy az 1990-es évek elején többen abban reménykedtek, hogy „a kelet-európaiaknak... Hayek, Friedman vagy Buchanan mellett a helyük" (Kovács [1994] 41. o.), azt mutatja, hogy 1994-ben még többek között Buchanan neve fémjelezte a „ausztro-amerikai típusú neoliberalizmust" (uo.) a közgazdász szakmában, bármit jelentsen is ez a kifejezés. Azóta azonban Buchanan sokkal kevésbé hivatkozott szerző, mint az itt említett másik két társa. Ha vezető hazai közgazdaság-tudományi lap, a Közgazdasági Szemle online elérhető (1995-) adatbázisát nézzük, akkor az eredmény az, hogy míg Hayekre 58 tanulmány hivatkozik, Friedmanra 80, addig Buchananre csak 34. Elmarad ez a szám Buchanan olyan, „neoliberálisnak” általában nem tekintett kortársaitól is, mint Arrow (74) vagy Samuelson (68). Miért e népszerütlenség? A könnyü válasz az, hogy egyszerüen követjük a világtrendet, hiszen Buchananre a világ közgazdaságtanában is sokkal kevesebbet hivatkoznak, mint az itt említett, szintén Nobel-díjas szerzőkre. Sőt Buchanant (és a virginiai stílusú politikai gazdaságtant) még a fóáramú politikai közgazdaságtan is mostohán kezeli (Blankart-Koester [2006]). Miért van ez?

A kézirat első változata 2017. augusztus 21-én érkezett szerkesztőségünkbe.

DOI: http://dx.doi.org/10.18414/KSZ.2017.10.1097 
Wagner kötete nem ezt a kérdést teszi fel, de a Buchanan munkásságát bemutató és továbbgondoló elemzése lehetővé teszi, hogy mi magunk válaszoljuk meg. Röviden azért, mert Buchanan a végletekig komolyan vette Hayek intését, miszerint „[a]ttól még, hogy egy fizikus csupán fizikus, első osztályú fizikus és a társadalom egyik leghasznosabb tagja lehet. Senki sem lehet azonban nagy közgazdász, aki csak közgazdász - sőt kísért a gondolat, hogy az a közgazdász, aki csak közgazdász, valószínüleg tehertétellé, de talán még kifejezetten veszélyessé is válik." (Hayek [1967/1956] 123. o.) Hogy ez mit jelent, sejteti a tartalomjegyzék is. Wagner hat részre osztva elemzi - és gondolja tovább, hangsúlyozva, hogy nem elmélettörténetet ír - Buchanan munkásságát, külön fejezetet szentelve a közösségi pénzügyekre vonatkozó általános megközelítésnek (2. fejezet), az alkotmányos politikai gazdaságtannak (3. fejezet), a föderalizmus gazdaságtanának (4. fejezet), az államadósság gazdaságtanának (5. fejezet), a szabadság és a felelősség viszonya, illetve a jóléti állam által felvetett problémáknak (6. fejezet, s végül az etikai és a társadalomfilozófiai kérdések tárgyalásának (7. fejezet). Ezt a hat fejezetet előzi meg az, amelyikben a szerző bemutatja Buchanant és a virginai public choice-iskolát (1. fejezet), a kötetet záró Függelék pedig Wagner személyesebb visszaemlékezéseit tartalmazza.

Mi fogja össze ezeket a szerteágazó témákat azon kívül, hogy ugyanazon elme gondolatairól van szó? Wagner könyve nem elmélettörténet, de van benne elmélettörténeti állítás is: az, hogy Buchanan „sün” (és nem „róka”) volt Isaiah Berlin metaforája szerint (3. o.), azaz egy nagy gondolata volt, amit aztán akkurátusan továbbgondolt és alkalmazott sok témában. E nagy gondolat pedig az, hogy a kormányzati akciókra is mint emberi interakciók eredményeire kell tekinteni - azaz úgy, ahogyan a piaci jelenségekre is szokás. Mivel Buchananben ez a gondolat már nagyon korán megfogalmazódott, 1949-es első cikke - s ez a másik elmélettörténeti állítása a könyvnek tartalmazza teljes további életművének csíráit (Buchanan [1949]).

Wagner interpretációja szerint Buchanan szándéka az volt, hogy alternatív közpénzügyi elméletet építsen fel, felismerve azt is, hogy nem létezik ilyen anélkül, hogy ne tennénk explicitté a politikai filozófiai feltevéseinket (42. o.). Az ortodox közpénzügyi elméletben ugyanis a politikai filozófia implicit, s ezen implicit politikai filozófia szerint a közgazdász egy abszolút hatalommal rendelkező monarchának ad tanácsokat. Ha ettől eltérő politikai berendezkedést tételezünk fel, akkor az ortodox receptek nem müködnek. Nincs közpénzügyi elmélet tehát anélkül, hogy megfogalmaznánk, milyen politikai rendszert tételezünk fel, s milyen politikai filozófián alapszik ez a politikai rendszer. Így jut el Buchanan a közpénzügyektől a demokratikus politikai berendezkedés és a hatalom alkotmányos korlátainak közgazdasági elemzéséig, s onnan a politikai filozófiai és erkölcsi kérdésekig.

Wagneré persze sajátos - ahogy Roger Congleton mondja a könyv ajánlásában a hátlapon: „,neoosztrák” - és jóindulatú nézőpont, de nem kerüli meg Buchanan életének és munkásságának elkerülhetetlen ellentmondásait. Néhány ilyen szembetünő ellentmondás - feloldásuk nehézsége alapján növekvő sorrendben - a következö.

Az első ellentmondás a gazdaságpolitikai relevanciára való törekvés és a gazdaságpolitikai tanácsadás elvetése között feszül. Buchanan alapvetően gazdaságpolitikai és közpénzügyi kérdésekkel foglalkozott, miközben haszontalannak tartotta a gazdaságpolitikai tanácsadást. Még a tekintélyes Council of Economic Advisors nevű tanácsadó 
testület megszüntetésére is javaslatot tett (14., 125. o.). Ezt az ellentmondást Wagner könnyen feloldja Buchanan alkotmányos politikai gazdaságtanának magyarázatával (3. fejezet). Mivel a gazdaságpolitika a politikai szereplők viselkedésének interakcióiból alakul ki, az ajánlásnak az ezeket irányító szabályokra kell vonatkoznia: a közgazdásznak az alkotmányozás utáni politikában nincs szerepe. Nincs értelme anélkül értékelni egy-egy gazdaságpolitikai javaslatot, hogy megkérdeznénk, a benne foglaltak milyen politikai szabályok mellett valósulhatnának meg.

Egy másik ellentmondás, hogy miközben Buchanan az amerikai történelem nagyjaihoz nyúlt vissza politikai filozófiájában, európai szerzőkhöz nyúlt vissza a közgazdaságtanban, és kifejezetten kritikus volt a közpénzügyi irodalom amerikai fóáramával szemben. Ízig-vérig amerikai volt, a vidékies és viszonylag szegény Délen született, és gyakorlatilag egész életét is ott töltötte. Az ebben a kultúrában jellemző, az északkeleti elittel szembeni ellenszenvet személyesebb hangvételü írásaiban nem lehet nem észrevenni (Buchanan [2007]). Ugyanakkor politikai gazdaságtani látásmódját sokkal inkább európai szerzők formálták, mint amerikaiak. Wagner részletesen bemutatja, hogyan találta meg Buchanan individualista-analitikus közpénzügyi szemléletmódjának alapjait (2. fejezet) a svéd Knut Wicksell (33-36. o.) és az olasz Antonio de Viti de Marco (37-38. o.) müveiben. Sőt Wagner szerint a 19-20. század fordulójának olasz közpénzügyi iskolája olyannyira hatással volt Buchananre és a virginiai public choiceiskolára, hogy utóbbit akár „olaszosított” klasszikus politikai gazdaságtannak (16. o.) is nevezhetnénk. Buchanan alkotmányos közgazdaságtani látásmódja pedig leginkább a mai német ordoliberalizmushoz áll közel (162-164. o.). Wagner ez utóbbi állítást szépen kifejti, mégsem foglalkozik Buchanannek a Viktor Vanberggel, a modern német ordoliberalizmus kiemelkedő alakjával közösen írt tanulmányaival.

Egy harmadik, Buchanan munkásságában rejlő ellentmondás a politikával szembeni pesszimizmus és az alkotmányos döntéshozatallal szembeni optimizmus ellentmondása. Buchanan a public choice, a „romantika nélküli politika” (Buchanan [1984]) tudományának alapító atyja, annak politikával kapcsolatos pesszimista látásmódját azonban nem fogadta el. ${ }^{1}$ Hitt benne, hogy a politika két - az alkotmányos és az alkotmányozás utáni - szintjének szétválasztásával a politika konszenzuális jellege megmenthető, és alkotmányos szinten elképzelhető a wickselli egyhangú egyetértés, s ezért az egyhangú egyetértés normatív kritériumként is hasznos. Ugyanakkor az ilyen alkotmányos döntések a mindennapi politikában vagy nagyon ritkák, vagy teljes mértékben összefolynak a napi politikai döntésekkel, s ritkán hozzák meg őket teljes konszenzussal. Wagner csak részben oldja fel ezt az ellentmondást azzal, hogy „effektív alkotmányról” (83. o.) beszél, amelybe nemcsak a formális alkotmány, hanem a politikát szabályozó íratlan normák is beletartoznak. Tehát amikor megváltozik a szereplők „morális képzelőereje” (moral imaginaton), megváltozik az effektív alkotmány is.

Buchanan radikális szubjektivizmusa és a szabadság morális alapjainak hangsúlyozása között is ellentmondás feszül. Buchanan „legsürübb” műve, a Cost and Choice

\footnotetext{
${ }^{1}$ Érdekes, hogy P. T. Bauer munkásságáról írott esszéjében Bauerre és Anthony de Jasayre hivatkozva sajátosan magyarnak nevezi azt a „demokratikus” pesszimizmust, amely a modern public choicetól sem áll távol (Buchanan [2005]).
} 
(Buchanan [1999/1969]) a wagneri értelmezés szerint az életmü megértésének kulcsa, mert ebben fogalmazza újra az általa követett szubjektivista közgazdaságtan alaptéziseit. Ez a vékonyka könyv, amely Wagner szerint „,annyi elméleti ütést tartalmaz oldalanként, amennyit egyetlen könyv sem a közgazdaságtan történetében” (6. o.), nem más, mint az alternatív költség jelentésének konzisztens végiggondolása azzal a következtetéssel, hogy az egyéni döntés és a költség nem választható szét egymástól, az alternatív költségek ezért nem figyelhetök meg objektív módon, a cselekvő személyétől függetlenül (46-52. o.). Hogyan figyelhetők meg akkor a preferenciákban megbújó erkölcsök, s honnan tudja egyáltalán Buchanan - ha hủ akar maradni radikális szubjektivista álláspontjához -, hogy milyen erkölcsök kellenek a liberális társadalmi rend fenntartásához? A feloldás talán az alkotmányos és az alkotmányozás utáni döntéshozatalra vonatkozó preferenciák eltéréseiben rejlik, de Wagner fejtegetéseiből ez nem olvasható ki. A könyv vége felé talán nem véletlenül jegyzi meg, hogy a Buchanan hatvanéves életművében óhatatlanul felmerülő feszültségek közül a szubjektivizmus kiterjesztése a legígéretesebb (172. o.).

Több olyan téma is megjelenik a kötetben, amely különösen aktuálisnak tünik. Az egyik ilyen az államadósság terheiről szóló rész (5. fejezet), amely annyira értően és „kerek” formában közvetíti a buchanani gondolatokat, hogy akár egy-egy haladóbb kurzuson olvasmányként is fel lehetne adni. Jól követhető logikával adja elő azt a régi és Buchanan által akkurátus logikával újragondolt és kidolgozott elméletet, miszerint az államadóssággal a jövő generációt terheljük, s nem magunknak tartozunk vele, ahogyan azt az 50-es évek keynesi ortodoxiája állította. Wagner nem is kérdőjelezi meg ezt a logikát, de megjegyzi, hogy Buchanan nem maradt teljesen hủ saját individualista elveihez, amikor „generációk” közötti tehermegosztásról beszélt (113. o.). Egy másik ilyen aktuálisnak tűnő téma a liberális társadalom és a bevándorlás viszonya, illetve a szabad vándorlás és a szabadkereskedelem közötti párhuzam vagy annak hiánya (166-168. o.). Ez a kérdés nincs olyan szépen kifejtve és végiggondolva, mint az államadósság terheinek kérdése, de azt világossá teszi Wagner, hogy a kérdés az előbb emlegetett effektív alkotmány, az ebben szerepet játszó morális szabályok és az ezek által definiált morális közösség fogalmait használva közelíthető meg. A vándorlás és a szabadkereskedelem ekvivalenciája tehát a Buchanan-féle alkotmányos politikai gazdaságtani keretben nem nyilvánvaló.

Wagner kötetének tehát inkább a buchanani életmü által inspirált kérdések felvetése és továbbgondolása a célja, s nem az életmübe vagy a virginiai politikai gazdaságtan eredményeibe való bevezetés. Ezért főleg olyanoknak ajánlható ez a könyv, akik a nyitott kérdésekre, az ezekkel foglalkozó irodalomra kíváncsiak, a továbbgondolás vagy alkalmazás szándékától vezérelve. Talán ezzel az úttörő szándékkal magyarázható az is, hogy a kötet szövege - sokszor szó szerint is - számos helyen átfed Wagner 2016os, nem kevésbé úttörő szándékú könyvével (Wagner [2016]).

A szubjektivizmusnak és a módszertani individualizmusnak a liberális gazdasági és politikai intézményrendszer elemzésében való konzisztens alkalmazása tehát nem könnyü feladat, hiszen még egy olyan kvalitású és olyan legendás munkafegyelemmel és munkabírással rendelkező közgazdásznak sem sikerült ellentmondások nélkül, mint James Buchanan. De talán ez nem is lehetséges, és talán éppen az a nagy tanulság, 
hogy a liberális társadalmi rend elválaszthatatlan velejárója, hogy e rend elméleti alapjait folyamatosan újra kell gondolni, az erről szóló nagy müveket újra kell értelmezni, $s$ az újraértelmezés által felvetett ellentmondásokat kutatási kérdésekké kell fogalmazni - úgy, ahogy Richard E. Wagner teszi Buchanan munkásságáról szóló mủvében.

\section{Hivatkozások}

Blankart, Ch. B.-Koester, G. B. [2006]: Political Economics versus Public Choice:. Two Views of Political Economy In Competition. Kyklos, Vol. 59. No. 2. 171-200. o. https://doi. org/10.1111/j.1467-6435.2006.00330.x.

Buchanan, J. M. [1949]: The Pure Theory of Government Finance: A Suggested Approach. Journal of Political Economy, Vol. 57. No. 6. 496-505. o. https://doi.org/10.1086/256880.

Buchanan, J. M. [1984]: Politics without Romance: A Sketch of Positive Public Choice Theory and Its Normative Implications. Megjelent: Buchanan, J. M.-Tollison, R. D. (szerk.): The Theory of Public Choice - II. The University of Michigan Press, Anne Arbor, 11-22. o.

Buchanan, J. M. [1999/1969]: The Collected Works of James Buchanan. Vol. 6. Cost and Choice: An Inquiry in Economic Theory. Liberty Fund, Indianapolis, IN.

Buchanan, J. M. [2005]: The Market, Yes; The Demos, No. Cato Journal, Vol. 25. No. 3. 461-464. o.

Buchanan, J. M. [2007]: Economics from the Outside In: "Better than Plowing” and Beyond. Texas A \& M University Press, College, Station, Texas.

Buchanan, J. M.-Wagner, R. E. [2000/1977]: The Collected Works of James Buchanan. Vol. 8. Democracy in Deficit: The Political Legacy of Lord Keynes. Liberty Fund, Indianapolis, IN.

Hayek, F. A. [1967/1956]: The Dilemma of Specialization. Megjelent: Hayek, F. A.: Studies in Philosophy, Politics, and Economics. Simon and Schuster, New York, 122-132. o.

Kovács János Mátyás [1994]: Az intézményi közgazdaságtan népszerüségéről. Mikor a kelet-európai közgazdászok liberális paradigmát keresnek. Megjelent: Madarász Aladár-Szabó Judit (szerk.): „Miért hagytuk, hogy így legyen?” Tanulmányok Bródy Andrásnak. Közgazdaság és Jogi Könyvkiadó, MTA Közgazdaságtudományi Intézete, Budapest, 41-51. o.

Rowley, Ch. K. [2008]: Public Choice and Constitutional Political Economy. Megjelent: Rowley, Ch. K.-Schneider, F. (szerk.): Readings in Public Choice and Constitutional Political Economy. Springer Science + Business Media, LLC, New York, NY, 3-29. o. https:// doi.org/10.1007/978-0-387-75870-1.

Wagner, R. E. [2016]: Politics as a Peculiar Business. Insights form a Theory of Entangled Political Economy. Edward Elgar, Cheltenham, UK, https://doi.org/10.1177/1478929917708748.

Czeglédi Pál

Czeglédi Pál a Debreceni Egyetem Gazdaságtudományi Karának docense (czegledi.pal@econ.unideb.hu). 